\title{
Pengembangan Komponen Tes Kondisi Fisik Berbasis Android
}

\section{Development of Android-Based Physical Condition Test Components}

\author{
Pandu Kresnapati', Danang Aji Setyawan ${ }^{2}$, Setiyawan ${ }^{3}$ \\ 1,2,3 FPIPSKR, Universitas PGRI Semarang, Indonesia \\ email: Pandukresnapati@upgris.ac.id², Danangajisetyawan@upgris.ac.id², Setiyawan@upgris.ac.id³
}

doi : https://doi.org/10.20884/1.paju.2020.2.1.3166

\begin{abstract}
Abstrak
Kemajuan teknologi, khususnya bidang smartphone android sedang berkembang pesat khususnya di Indonesia. Mengembangkan dan membuat penilaian tes kondisi fisik, serta membuat media yang layak digunakan untuk tes kondisi fisik berbasis android dapat menjadi sebuah solusi. Kelebihan aplikasi ini adalah terdapat petunjuk prosedur pelaksanaan 10 tes kondisi fisik, serta dapat mengetahui norma tes masing-masing yang dapat dengan mudah diakses oleh pelatih, guru, atlet, siswa ataupun orang tua siswa, melalui aplikasi dengan nama Tes Kondisi Fisik Olahraga. Metode dalam penelitian ini menggunakan penelitian Research \& Development dengan melibatkan 1 ahli media dan 1 ahli bidang materi. Hasil penelitian pengembangan instrumen norma tes kondisi fisik berbasis android dengan model aplikasi android. Berdasarkan hasil uji coba skala kecil untuk 16 atlet Futsal Kota Semarang yang kemudian diberikan jenis tes kondisi fisik. Dari 16 responden, terdapat 14 orang menyatakan sangat layak/sangat baik dengan persentase $93 \%$, sedangkan 2 menyatakan layak/baik dengan persentase $7 \%$. Berdasarkan hasil uji coba skala besar untuk 21 atlet Futsal Jawa Tengah. Dari 21 orang responden, terdapat 18 orang menyatakan sangat layak/sangat baik dengan persentase 92,16\%, 3 responden menyatakan layak/baik dengan persentase 7,84\%. Hasil dari pengembangan menggunakan model aplikasi berbasis android dinyatakan layak untuk diuji coba secara umum. Penggunaan aplikasi berbasis android dapat membantu pelatih atau guru untuk dapat lebih efisien dalam mengetahui norma dan nilai tes kondisi fisik secara digital.
\end{abstract}

Kata Kunci : Aplikasi, Android, Instrumen Tes, Kondisi Fisik

\begin{abstract}
Advances in technological, especially in the field of Android smartphones, are growing rapidly, especially in Indonesia, we should use this media as a learning tool to increase our knowledge. In this case, develop and make physical condition test assessments and make media suitable for use for Android-based physical condition tests. The advantages of this application are that there are instructions for the implementation of 10 tests of physical conditions, and can find out the norms of each test which can be easily accessed by coaches, teachers, athletes, students or parents of students, through an application called the Sports Physical Condition Test. The method in this study uses Research \& Development research involving 1 media expert and 1 material expert. The
\end{abstract}

Alamat Koresponden: FPIPSKR, Universitas PGRI Semarang, Indonesia

Email : Pandukresnapati@upgris.ac.id 
results of the research on the development of an android-based physical condition test norm instrument with an android application model. Based on the results of small-scale trials for 16 Futsal athletes in Semarang City who were then given the type of physical condition test. Of the 16 respondents, 14 people stated that they were very feasible/very good with a percentage of $93 \%$, while 2 stated that they were feasible/good with a percentage of $7 \%$. Based on the results of large-scale trials for 21 Futsal athletes in Central Java. Of the 21 respondents, there were 18 people who stated very feasible/very good with a percentage of $92.16 \%, 3$ respondents stated that they were feasible/good with a percentage of $7.84 \%$. The results of the development using an android-based application model are declared feasible to be tested in general. For trainers, physical education teachers need to add insight into technological developments so well and can help in taking physical condition test norms by using the Sports Physical Condition Test application, with this Android-based application the coach or teacher can be more efficient in knowing the norm value of the physical condition test digitally .

Keywords : Android, Application, Physical Condition, Test Instrument

\section{PENDAHULUAN}

Pada kehidupan yang telah maju dan modern sekarang ini olahraga sudah dipandang sebagai kebutuhan hidup sehari-hari yang sangat penting, karena banyak sekali manfaat olahraga baik untuk menjaga kondisi fisik seseorang maupun bertujuan untuk meningkatkan kesehatan dalam rangka agar meningkatkan kualitas hidup manusia. Oleh karena itu olahraga berperan aktif dalam meningkatkan kualitas kesehatan manusia yang seutuhnya yakni sehat jasmani dan rohani. Meja, Dini, \& Kota (2015) menjelaskan Olahraga merupakan salah satu bentuk aktivitas fisik yang memiliki dimensi kompleks. Mengingat kemajuan perkembangan teknologi khususnya di bidang smartphone android yang sedang berkembang pesat di pasaran khususnya di Indonesia kita hendaknya menggunakan media ini sebagai alat pembelajaran untuk meningkatkan pengetahuan kita. Teknologi multimedia yang dimana perkembangannya cukup pesat saat ini adalah Augmented Reality.

Perkembangan ilmu teknologi informasi saat ini sangat pesat dan banyak cabang ilmu pengetahuan lain mempergunakan teknologi informasi untuk mempermudah dan menyelesaikan permasalahan yang ada saat ini. Dengan berbagai cabang ilmu pengetahuan dan teknologi, pengembangan teknologi informasi nampaknya seakan tanpa batas dalam perkembangan saat ini banyak cabang ilmu pengetahuan lain mempergunakan teknologi informasi untuk mempermudah maupun menyelesaikan 
Pandu Kresnapati, Danang Aji Setyawan, Setiyawan | Pengembangan Komponen Tes Kondisi Fisik Berbasis Android

permasalahan yang ada, dengan keterkaitan berbagai cabang ilmu pengetahuan dan pengembangan teknologi informasi. Sekarang ini sudah berkembang pesat penguasaanya dalam dunia teknologi, hal ini dapat dilihat dari aktivitas sehari-hari yang kebanyakan digunakan untuk bermain gadget dan sosial media. (Royana, 2018).

Perkembangan teknologi informasi yang semakin pesat di era globalisasi saat ini tidak bisa dapat kita dihindari lagi pengaruhnya terhadap dunia pendidikan. Tuntutan global menuntut dunia pendidikan dan yang dirasa selama ini untuk dapat selalu dan senantiasa menyesuaikan perkembangan teknologi terhadap usaha dalam peningkatan mutu pendidikan,terutama penyesuaian penggunaannya bagi dunia pendidikan khususnya dalam proses pembelajaran (Budiman, 2017). Berbeda dengan melakukan secara manual yang lebih banyak memiliki kekurangan, Kekurangan dari cara manual yaitu terlalu banyak memerlukan orang untuk mencatat hasil (Gumelar, Ray, \& Ugelta, 2017). Secara istilah pengertian aplikasi adalah suatu program yang siap untuk digunakan yang dibuat untuk melaksanankan suatu fungsi bagi pengguna jasa aplikasi serta penggunaan aplikasi lain yang dapat digunakan oleh suatu sasaran yang akan dituju. Aplikasi mempunyai arti yaitu pemecahan masalah yang menggunakan salah satu tehnik pemrosesan data aplikasi yang biasanya berpacu pada sebuah komputansi yang diinginkan atau diharapkan maupun pemrosesan data yang di harapkan (Andi, 2015; Listiandi et al., 2020).

Dari fakta inilah guru dan pelatih harus dituntut untuk dapat mengikuti perkembangan teknologi agar pembelajaran atau pelatihan supaya menjadi lebih inovatif. Penggunaan komputer dalam teknologi terkini yaitu multimedia dan internet mampu memberikan kesempatan luas kepada guru dan siswa serta memberikan makna baru dalam pembelajaran (Royana, 2018). Makna baru yang dimaksud di sini adalah pemanfaatan perkembangan teknologi dalam proses pelatihan dan belajar mengajar. Seperti yang kita tahu bahwa anak-anak pada masa sekarang ini sudah berkembang pesat penguasaanya dalam dunia teknologi dalam kehidupan sehari-hari.

Untuk mengetahui kondisi fisik seorang atlet diperlukan adanya pengukuran secara berkelanjutan dengan alat ukur yang tepat sesuai dengan karakter atlet, umur yang bersamaan dengan pertumbuhan dan perkembangan, budaya, agama, latar belakang sosial dan aktivitas keseharian yang dapat mempengaruhi kondisi fisik. Latihan fisik secara teratur akan dapat memberi rangsangan kepada semua sistem tubuh sehingga dapat mempertahankan tubuh tetap dalam keadaan sehat. Olahraga juga bertujuan untuk 
rekreasi dan untuk mencapai suatu prestasi dalam suatu kejuaraan. Latihan fisik yang baik adalah olahraga yang dilakukan secara teratur dengan memperhatikan kemampuan tubuh dan sesuai dengan takaran berolah raga. Atlet sering melakukan pelatihan fisik yang berlebihan untuk mempersiapkan diri dalam menghadapi suatu kejuaraan atau pertandingan dalam waktu yang singkat (Bafirman, 2019).

Pada alat ukur yang umum dipakai para guru atau pelatih olahraga untuk mengetahui kondisi fisik, antara lain dengan tes kecepatan adalah pencatat waktu manual, misalnya stopwatch. Saat ini stopwatch banyak digunakan karena ukurannya yang kecil, mudah dibawa kemana - mana, dan praktis. Sistem pengoperasian stopwatch sangatlah terbatas. Data waktu yang sudah ada pada stopwatch secara manual harus dipindahkan kedalam daftar atlet kemudian dikonversikan kedalam nilai kondisi fisik yang ada. Setelah itu diolah dengan data nilai - lainnya. Permasalahan tidak adanya alat bantu pencatatan tes kecepatan ini juga dialami oleh sebagian besar pelatih - pelatih olahraga prestasi.

Salah satu refensi terkait dengan "Pengembangan Multimedia Pembelajaran Senam Lantai Berbasis android pada pendidikan jasmani olahraga dan Kesehatan di SMA" tentang Produk yang dihasilkan dalam penelitian ini adalah aplikasi pembelajaran senam lantai berbasis android dengan nama "MyGymnastic" yang dapat diunduh secara gratis di dalam playstore. Selain itu produk yang dihasilkan adalah buku panduan penggunaan aplikasi MyGymnastic dan DVD berisi panduan dan review aplikasi MyGymnastic. Indikator keberhasilan produk ini adalah berupa lembar penilaian dari ahli materi dan ahli media terhadap produk multimedia pembelajaran senam lantai berbasis android. (Titting, Fellyson, Hidayah, Taufik, Pramono, 2016).

Dari referensi penelitian lainnya mengenai Pengembangan Akselerometer Running Monitor Berbasis Android Untuk Mengetahui Karakteristik Lari Jarak Pendek Hasil penelitian menunjukkan bahwa akselerometer pada android dapat mengirimkan data dan diolah oleh program yang telah dibuat. Program selanjutnya menampilkan informasi karakteristik lari yaitu kecepatan, panjang dan frekuensi langkah. Sistem dan aplikasi untuk mengetahui percepatan, dan mengestimasi kecepatan dan jarak tempuh pelari telah berhasil diimplementasikan sehingga pelari maupun pelatih dapat mengetahui kelemahan dari pelari di jarak maupun detik tertentu sehingga dari sana dapat diperbaiki dan dilakukan pelatihan sehingga diharapkan atlet dapat mencapai jarak 100 meter dalam waktu yang lebih singkat. Pada sistem ini, di smartphone Android hanya digunakan untuk 
Pandu Kresnapati, Danang Aji Setyawan, Setiyawan | Pengembangan Komponen Tes Kondisi Fisik Berbasis Android

merekam data percepatan pelari dan disimpan pada memory baik internal maupun eksternal. Namun, untuk pengolah data percepatan, estimasi jarak dan posisi, flter kalman dilakukan pada PC. Untuk tahapan berikutnya dapat dikembangkan pengolahan data, tersebut langsung dilakukan pada smartphone Android sehingga setelah berlari, atlet maupun pelatih dapat langsung menganalisis hasil yang dicapai pelari, tidak perlu memindahkan datanya ke PC terlebih dahulu (Lari \& Pendek, 2017).

Subarjah (2013) menjelaskan kondisi fisik yang baik yaitu ada peningkatan dalam kemampuan sistem sirkulasi dan kerja jantung. Terjadi peningkatan dalam kekuatan, kelentukan, stamina, kecepatan, dan komponen kondisi fisik lainnya, akan meningkatkan efektifitas dan efesiensi gerak kearah yang lebih baik, waktu pemulihan akan lebih cepat, respon bergerak lebih cepat apabila dibutuhkan kondisi fisik terdiri dari beberapa komponen-komponen yang ada pada tubuh dan pada semua cabang olahraga komponen yang dibutuhkan tidaklah berbeda yang membedakan terdapat pada proses latihan komponen kondisi fisik yang diberikan akan lebih spesifik pada setiap cabang olahraga. Secara umum yang dominan komponen kondisi fisik yang semua ada pada cabang olahraga meliputi kekuatan (strength), kecepatan (speed), daya tahan (endurance), kelincahan (Agility), kelentukan (flexibilitas), koordinasi (coordination), Reaksi (reaction) (Hidayat, Budi, Purnamasari, Febriani, \& Listiandi, 2020; Kusuma, Nurcahyo, \& Alivian, 2019; Nanang, Fuad, Didik, Topo, \& Panuwun, 2018). Selain itu terdapat beberapa komponen konsisi fisikyang lebih khusus sesuai dengan kebutuhan cabang olahraga masing-masing. Kebutuhan ini berdasarkan setiap cabang olahraga yang memilikikarakteristik yang berbeda dari olahraga yang lain sehingga membutuhkan beberapa kondisi fisik tambahan pada olahraga tersebut.

Kondisi fisik adalah satu persyaratan yang diperlukan dalam usaha peningkatan prestasi atlet, bahkan dapat dikatakan sebagai keperluan dasar yang tidak dapat ditunda atau ditawar-tawar lagi. Kondisi fisik adalah satu kesatuan dari komponen-komponen yang tidak dapat dipisahkan begitu saja, baik peningkatan maupun pemeliharaannya. Yuyun (2012) Kondisi fisik memiliki peran dominan dalam tingkat kebugaran jasmani seseorang yang beraktifitas dalam olahraga. Memiliki kondisi fisik yang baik berarti memilikim kebugaran jasmani dan kemampuan fungsional tubuh yang baik juga. Atlet olahraga yang memiliki kondisi fisik yang baik kondisi tubuhnya baik dan dapat melakukan segala aktivitas dalam olahraga yang mereka lakukan. (Umam, Setiawan, \& Pratama, 2020). 
Kondisi fisik yang baik akan sangat berpengaruh terhadap fungsi dan system organism tubuh, antara lain berupa: a. Akan ada peningkatan dalam kemampuan sistem sirkulasi dan kerja jantung. b. Akan ada peningkatan dalam kekuatan, stamina, dan kondisi fisik lainnya. c. Akan ada ekonomi gerak yang lebih baik pada waktu latihan. d.Akan ada pemulihan yang lebih cepat dalam organ-organ tubuh setelah latihan. e. Akan ada respon yang cepat dari organisme tubuh kita apabila sewaktuwaktu respon demikian diperlukan (Suherman, 2019).

Tujuan penelitian ini adalah membuat penilain tes kondisi fisik dan membuat media yang layak digunakan untuk tes kondisi fisik terpadu berbasis android. Kelebihan dari aplikasi ini adalah merpermudah penghituhan untuk mengtahui norma - norma tes kondisi fisik dan terdapat petunjuk prosedur pelaksanaan tes kondisi fisik yang menggunakan bahasa Indonesia, dengan rentan usia pelajar serta berbagai jenis tes kondisi fisik lainya, meliputi tes kekuatan, kecepatan, kelincahan kelentukan, daya tahan, daya ledak koordinasi, keseimbangan, daya lentur, dan reaksi serta dapat mengetahui norma tes masing-masing yang dapat dengan mudah diakses oleh pelatih maupun guru, atlet, siswa ataupun orang tua siswa, nantinya aplikasi ini oleh peneliti diberi nama Tes Kondisi Fisik.

Aplikasi Tes Kondisi Fisik adalah aplikasi pengembangan tes kondisi fisik android yang memiliki ciri khas berupa pengembangan mengenai tes-tes kondisi fisik. Aplikasi yang akan dibuat dengan berbasis android dan dapat diunduh di dalam playstore. Playstore merupakan aplikasi bawaan dari android dan aplikasi playstore ini merupakan aplikasi tempat mengunduh semua aplikasi - aplikasi berbasis android. Athoillah \& Irawan (2014) menjelaskan Android merupakan platform mobile yang mampu secara langsung berkomunikasi dengan berbagai database server, sehingga pada perkembangannya banyak bermunculan aplikasi-aplikasi berbasis data yang dikembangkan pada platform ini, misalnya saja facebook, twitter, instagram dan media sosial lainnya yang memungkinkan para penggunanya berbagi foto, musik dan data-data lainnya dengan lebih praktis karena tanpa harus membuka browser terlebih dahulu. Konsep pembinaan atlet berbakat sangat tergantung pada penerapannya kedalam sistem penyelenggaraan pelatihan. Pusat pendidikan dan pembinaan atlet pelajar berbakat merupakan wujud dari sistem penyelenggaraan pelatihan untuk mencapai hasil yang diinginkan yaitu atlet berprestasi (Rohman, 2019). 
Pandu Kresnapati, Danang Aji Setyawan, Setiyawan | Pengembangan Komponen Tes Kondisi Fisik Berbasis Android

\section{METODE}

Metode penelitian dan pengembangan atau dalam bahasa inggrisnya Research and Develompment adalah metode penelitian yang digunakan untuk menghasilkan produk tertentu, dan menguji keefektifan produk tersebut. Sugiyono (2016) menjelakan Langkah pertama dalam penelitian ini adalah mencari temuan penelitian produk dan menemukan kelemahan dari produk penelitian kemudian mengembangkan untuk menutup kelemahan dari temuan penelitian tersebut. Prosedur pengembangan pada penelitian pengembangan norma tes intrumen kondisi fisik berbasis android pada atlet futsal ini dilakukan dalam berbagai tahap.

Pembuatan Produk: Aplikasi kondisi kondisi berbasis android ini dibuat oleh tim pembuat aplikasi. Satu tim terdiri dari tiga orang yang memiliki tugas tersendiri dalam pembuatan aplikasi. Secara lebih terperinci tugas dan penjabarannya sebagai berikut: a. Layout dan Desain peneliti sekaligus termasuk dalam tim pembuat aplikasi pembelajaran renang berbasis android bertugas membuat sebuah tampilan-tampilan seperti apa nantinya bentuk aplikasi yang dibuat. . b. Aplication Development Pengembangan sekaligus building aplikasi dibuat oleh Nissa. Dalam Application Development nantinya bertugas membuat aplikasi siap pakai. Dari mulai coding sampai dengan penyelesaian sebuah aplikasi dikerjakan dalam tahapan ini. Uji coba lapangan dilakukan untuk mendapatkan tanggapan serta revisi produk, sehingga akan dihasilkan produk akhir berupa aplikasi norma tes instrumen kondisi fisik berbasis android.

Uji coba dilakukan dalam uji coba skala kecil dan uji coba skala besar. Setelah uji coba skala kecil dilakukan analisis dan revisi produk sebelum dilakukan uji coba skala besar. Setelah dilakukan uji coba skala besar tahapan selanjutnya adalah analisis akhir dan revisi akhir sehingga dihasilkan produk akhir yang siap digunakan. Revisi produk Setelah mendapatkan perbaikan dari para ahli, uji coba skala kecil dan uji coba skala besar untuk memperbaiki produk sebelum produk akhir digunakan di lapangan. Langkahlangkah prosedur Metode Research and Development (R\&D). 


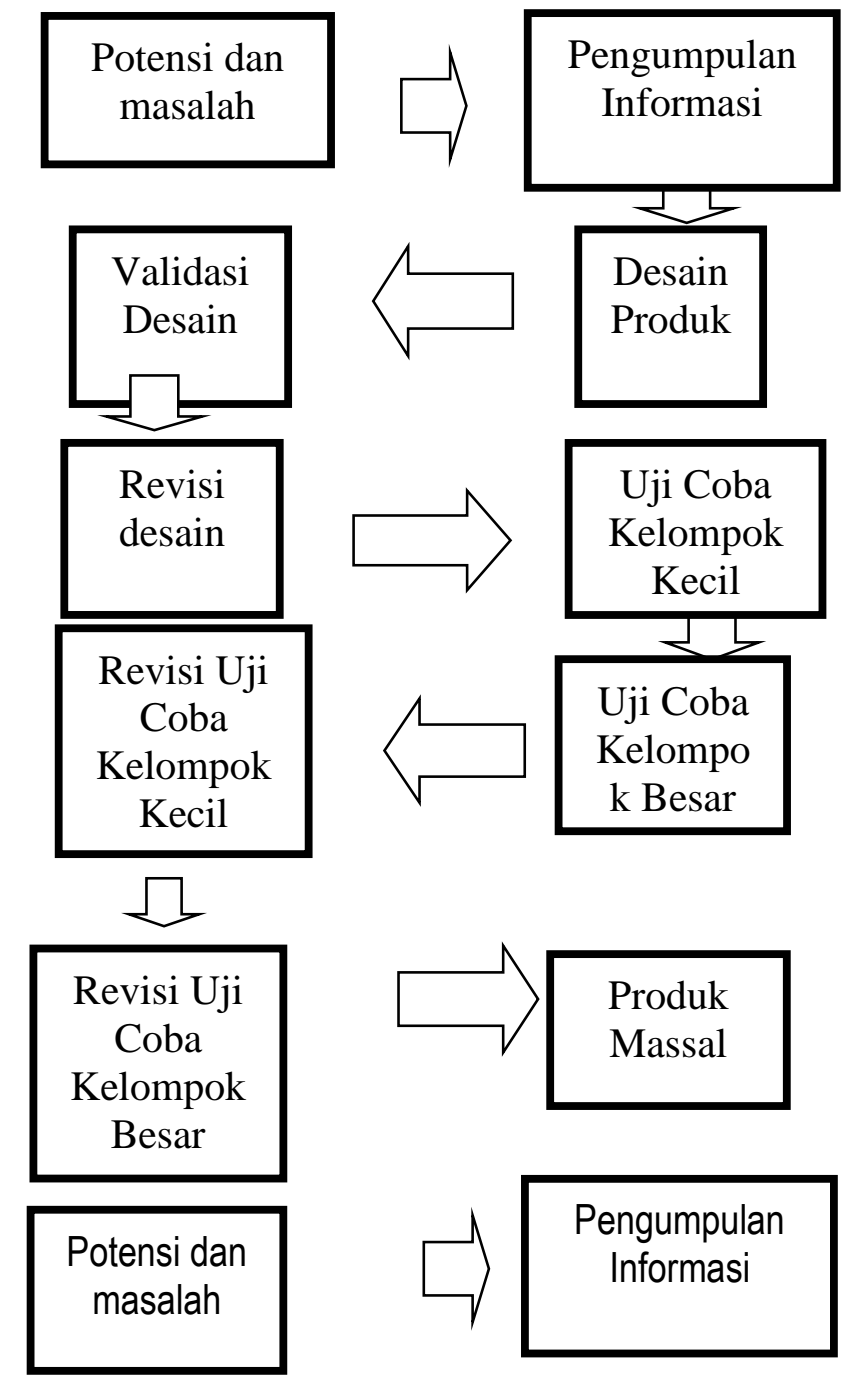

Gambar 1. Langkah-Langkah RnD (Sugiyono, 2016)

HASIL

Hasil dari desain yang dilakukan adalah aplikasi instrumen kondisi fisik berbasis android pada pemain futsal Kota Semarang, meliputi kefektifian untuk mengetahui norma tes kondisi fisik secara umum. Melakukan validasi produk kepada para ahli yang berkompeten dibidangnya. Validasi desain produk awal dalam hal ini adalah ahli materi dan ahli media. Produk awal dalam penelitian ini adalah berupa aplikasi intrumen norma tes kondisi fisik bebasis android untuk umum oleh ahli. 1 ahli materi dan 1 ahli media. 


\section{Hasil Validasi Ahli Materi}

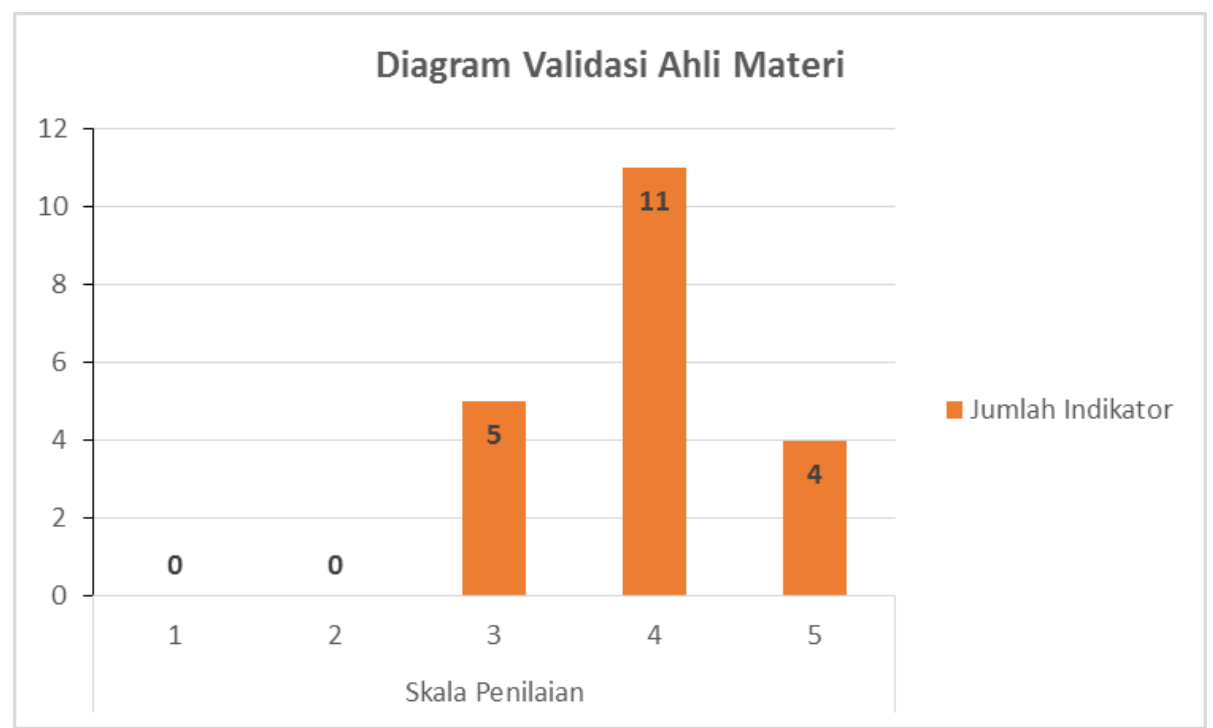

Gambar 2. Diagram Validasi Ahli Materi

Berdasarkan hasil penilaian ahli materi pada tabel diatas, diperoleh skor 79 dari skor maksimal 100. Item pertanyaan dalam penilian terdiri dari 20 item pertanyaan, terdapat 5 item pertanyaan yang menyatakan "cukup layak/cukup", "baik" dengan jumlah skor sebesar 15, terdapat 11 item pertanyaan yang menyatakan "baik/layak" dengan jumlah skor sebesar 44 dan 4 item pertanyaan menyatakan "sangat layak/sangat baik" dengan jumlah skor sebesar 20. Sehingga dari 20 item pertanyaan , hasil validasi dari ahli materi memiliki skor total sebesar 79 termasuk dalam kategori "Layak/Baik" model norma tes kondisi fisik dengan aplikasi berbasis android.

\section{Hasil Validasi Media Tes Kondisi Fisik}

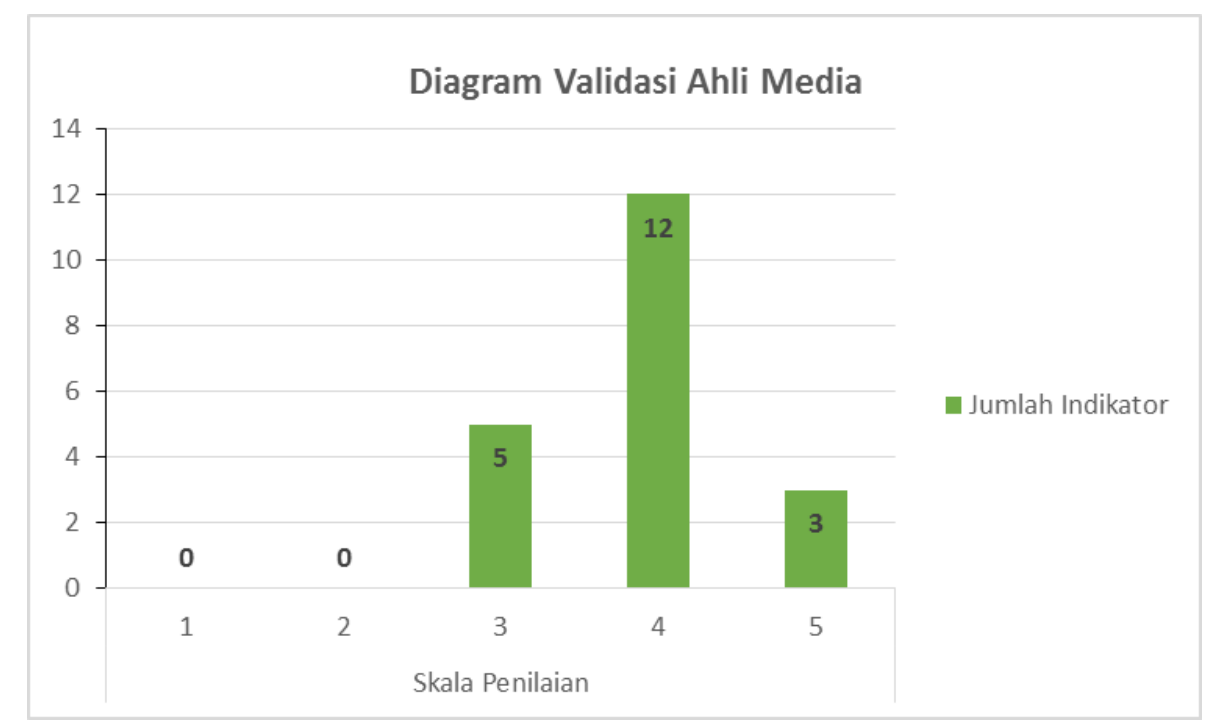

Gambar 3. Diagram Validasi Ahli Media 
Berdasarkan hasil penilaian ahli media pada tabel diatas, diperoleh skor 77 dari skor maksimal 100. Item pertanyaan dalam penilian terdiri dari 20 item pertanyaan, terdapat 6 item pertanyaan yang menyatakan "cukup layak/cukup", "baik" dengan jumlah skor sebesar 18, terdapat 11 item pertanyaan yang menyatakan "baik/layak" dengan jumlah skor sebesar 44 dan 3 item pertanyaan menyatakan "sangat layak/sangat", "baik" dengan jumlah skor sebesar 15 . Sehingga dari 20 item pertanyaan, hasil validasi dari ahli media memiliki skor total sebesar 77 termasuk dalam kategori "Layak/Baik" model norma tes kondisi fisik dengan aplikasi berbasis android.

Tabel 1. Hasil Skala Kecil Tes Kondisi Fisik

\begin{tabular}{ccccc}
\hline No & Nama & Skor & Hasil (\%) & Keterangan \\
\hline 1 & J.K.D & 99 & $80,20 \%$ & Baik \\
\hline 2 & R.F & 108 & $85,80 \%$ & Sangat Baik \\
\hline 3 & K.A.D & 95 & $77,00 \%$ & Baik \\
\hline 4 & Y.R.H & 113 & $91,00 \%$ & Sangat Baik \\
\hline 5 & K.M & 107 & $84,80 \%$ & Sangat Baik \\
\hline 6 & D.S & 106 & $85,60 \%$ & Sangat Baik \\
\hline 7 & N.KH & 100 & $79,90 \%$ & Baik \\
\hline 8 & E.J & 112 & $88,80 \%$ & Sangat Baik \\
\hline 9 & K.R.D & 115 & $91,70 \%$ & Sangat Baik \\
\hline 10 & B.S & 104 & $85,62 \%$ & Sangat Baik \\
\hline 11 & R.J & 102 & $92,40 \%$ & Sangat Baik \\
\hline 12 & M.R & 114 & $84,30 \%$ & Sangat Baik \\
\hline 13 & F.B.S & 106 & $87,50 \%$ & Sangat Baik \\
\hline 14 & G.D.P & 98 & $83,10 \%$ & Sangat Baik \\
\hline 15 & R.M.D & 106 & $91,10 \%$ & Sangat Baik \\
\hline 16 & M.K & 112 & $91,70 \%$ & Sangat Baik \\
\hline
\end{tabular}

(Sumber: Uji Coba Skala Kecil, 2020)

Berdasarkan hasil uji coba lapangan pada skala kecil untuk 16 atlet Futsal Kota Semarang. Diperoleh hasil bahwa dari 16 orang responden dan terdapat 14 orang menyatakan sangat layak/sangat baik dengan persentase $93 \%$, sedangkan 2 menyatakan layak/baik dengan persentase $7 \%$ sehingga dikatakan Baik/Layak. Skor Tertinggi pada hasil uji coba lapanagan skala kecil sebesar $115(91,70 \%)$ dan skor terendah pada hasil uji coba lapangan skala kecil sebesar 95 (77.00\%). 
Pandu Kresnapati, Danang Aji Setyawan, Setiyawan | Pengembangan Komponen Tes Kondisi Fisik Berbasis Android

Tabel 2. Hasil Uji Coba Lapangan Skala Besar Tes Kondisi Fisik

\begin{tabular}{ccccc}
\hline No & Nama & Skor & Hasil (\%) & Keterangan \\
\hline 1 & F.H & 114 & $84,80 \%$ & Sangat Baik \\
\hline 2 & D. N.A & 106 & $90,40 \%$ & Sangat Baik \\
\hline 3 & A.S & 108 & $84,80 \%$ & Sangat Baik \\
\hline 4 & R.A & 106 & $88,00 \%$ & Sangat Baik \\
\hline 5 & F.A & 113 & $85,60 \%$ & Sangat Baik \\
\hline 6 & M.A & 99 & $88,00 \%$ & Sangat Baik \\
\hline 7 & D.S & 102 & $83,20 \%$ & Sangat Baik \\
\hline 8 & K.D & 113 & $87,20 \%$ & Sangat Baik \\
\hline 9 & K.P & 96 & $88,80 \%$ & Baik \\
\hline 10 & B.S & 110 & $87,20 \%$ & Sangat Baik \\
\hline 11 & G.D & 98 & $84,80 \%$ & Baik \\
\hline 12 & R.K & 110 & $90,40 \%$ & Sangat Baik \\
\hline 13 & P.G.M & 104 & $78,40 \%$ & Sangat Baik \\
\hline 14 & K.H & 109 & $87,20 \%$ & Sangat Baik \\
\hline 15 & A.R & 110 & $91,20 \%$ & Sangat Baik \\
\hline 16 & R.E.G & 96 & $93,60 \%$ & Baik \\
\hline 17 & K.N & 107 & $80,10 \%$ & Sangat Baik \\
\hline 18 & M.S & 110 & $85,90 \%$ & Sangat Baik \\
\hline 19 & N.Z & 119 & $92,60 \%$ & Sangat Baik \\
\hline 20 & A.P & 113 & $91,10 \%$ & Sangat Baik \\
\hline 21 & R.H & 105 & $79,20 \%$ & Sangat Baik \\
\hline
\end{tabular}

(Sumber: Uji Coba Skala Besar, 2020)

Berdasarkan hasil uji coba lapangan pada skala besar untuk 21 atlet Futsal AFP Jateng. Diperoleh hasil bahwa dari Dari 21 orang responden, terdapat 18 orang menyatakan sangat layak/sangat baik dengan persentase $92,16 \%$, dengan 3 responden menyatakan layak/baik dengan persentase 7,84\%. Skor Tertinggi pada hasil uji coba lapanagan skala besar sebesar 119 (93,60\%) dan skor terendah pada hasil uji coba lapangan skala besar sebesar $96(88,80 \%)$. 


\section{PEMBAHASAN}

Dalam kegiatan olahraga, kondisi fisik seseorang mempengaruhi bahkan menentukan penampilan dan performanya. Oleh karena itu, program latihan kondisi fisik harus ditata, dirancang secara sistematis agar dapat meningkatkan dan menjaga kebugaran yang dibutuhkan didalam pencapaian sebuah prestasi optimal. Untuk mengetahui kondisi fisik seorang atlet diperlukan adanya pengukuran secara berkelanjutan dengan alat ukur yang tepat, alat ukur yang umum dipakai para guru atau pelatih olahraga untuk mengetahui kondisi fisik, antara lain dengan tes kecepatan adalah pencatat waktu manual, misalnya stopwatch. Oleh karena itu, agar lebih efektif dan sesuai dengan perkembanagan teknologi.

1. Hasil Validasi Ahli Materi

Berdasarkan hasil validasi yang dilakukan oleh ahli materi terhadap norma tes kondisi fisik para atlet. Diperoleh skor 79 dari skor maksimal 100. Dari 20 item pertanyaan, 5 item pertanyaan menyatakan cukup layak/cukup baik, 11 item pertanyaan menyatakan baik/layak dan 4 iterm pertanyaan menyatakan sangat layak/sangat baik. Dimana persentase kelayakan sebesar 79\% yang termasuk kategori "Layak/Baik".

2. Hasil Validasi Ahli Media

Berdasarkan hasil validasi yang dilakukan oleh ahli materi terhadap aplikasi yang digunakan untuk tes kondisi fisik para atlet yaitu Tes Komponen kondisi fisik. Diperoleh skor 77 dari skor maksimal 100. Dari 20 item pertanyaan, 6 item pertanyaan menyatakan cukup layak/cukup baik, 11 item pertanyaan menyatakan baik/layak dan 3 iterm pertanyaan menyatakan sangat layak/sangat baik. Dimana persentas kelayakan sebesar $77 \%$ yang termasuk dalam kategori "Layak/Baik".

3. Hasil Uji Coba Skala Kecil

Berdasarkan hasil uji coba lapangan pada skala kecil untuk 16 atlet Futsal Kota Semarang. Diperoleh hasil bahwa dari 16 orang responden dan terdapat 14 orang menyatakan sangat layak/sangat baik dengan persentase 93\%, sedangkan 2 menyatakan layak/baik dengan persentase 7\% sehingga dikatakan Baik/Layak.

\section{Hasil Uji Coba Skala Besar}

Berdasarkan hasil uji coba lapangan pada skala besar untuk 21 atlet Futsal AFP Jateng. Diperoleh hasil bahwa dari Dari 21 orang responden, terdapat 18 orang 
Pandu Kresnapati, Danang Aji Setyawan, Setiyawan | Pengembangan Komponen Tes Kondisi Fisik Berbasis Android

menyatakan sangat layak/sangat baik dengan persentase $92,16 \%$, dengan 3 responden menyatakan layak/baik dengan persentase $7,84 \%$.

\section{SIMPULAN}

Berdasarkan hasil dari uji coba lapangan pada sakala kecil untuk 16 orang responden dan terdapat 14 orang responden menyatakan sangat layak/sangat baik dengan persentase 93\%, sedangkan 2 orang responden menyatakan layak/baik dengan persentase $7 \%$ sehingga hasil uji coba skala kecil dapat dinyatakan layak/baik untuk digunakan. Skor tertinggi dalam uji coba skala kecil sebesar 95 (77.00\%). Berdasarkan uji coba lapangan skala besar untuk 21 atlet AFP Jateng. Diperoleh hasil bahwa dari 21 orang responden terdapat 18 orang responden menyatakan sangat layak/baik dengan persentase 92,16\%, dengan 3 responden menyatakan layak/baik dengan persentase 7,84. Skor tertinggi pada hasil uji coba lapangan skala besar 119 (92,60\%) dan skor terendah pada hasil uji coba skala besar sebesar 96\% (8,80\%). Dari deskripsi tersebut maka dapat disimpulkan bahwa tes instrument kondisi fisik berbasis android dapat digunakan untuk keperluan pengambilan data kondisi fisik atlet maupun olahragawan secara teknologi.

\section{REFERENSI}

Andi, J. (2015). Pembangunan Aplikasi Child Tracker Berbasis Assisted - Global Positioning System ( A-GPS ) Dengan Platform Android. Jurnal IImiah Komputer Dan Informatika (KOMPUTA), 1(1), 1-8.

Athoillah, \& Irawan. (2014). Mobile Berbasis Android Untuk. Perancangan Sistem Informasi Mobile Berbasis Android Untuk Kontrolpersediaan Barang Di Gudang, 1(January), 16.

Budiman, H. (2017). Peran Teknologi Informasi Dan Komunikasi Dalam Pendidikan. AlTadzkiyyah: Jurnal Pendidikan Islam, 8(1), 31. https://doi.org/10.24042/atjpi.v8i1.2095

Gumelar, M. I., Ray, H. R. D., \& Ugelta, S. (2017). Pengembangan Software Aerobic Capacity Dengan Menggunakan Bleep Test Berbasis Aplikasi Android. Jurnal Terapan IImu Keolahragaan, 2(1), 25. https://doi.org/10.17509/jikor.v2i1.4177

Hidayat, R., Budi, D. R., Purnamasari, A. D., Febriani, A. R., \& Listiandi, A. D. (2020). Faktor Fisik Dominan Penentu Keterampilan Bermain Sepak Takraw. Jurnal 
MensSana. https://doi.org/10.24036/jm.v5i1.127

Kusuma, I. J., Nurcahyo, P. J., \& Alivian, G. N. (2019). Komponen Biomotor Dominan Pada Permainan Tradisonal Dul-Dulan Khas Banyumas. Physical Activity Journal. https://doi.org/10.20884/1.paju.2019.1.1.2000

Lari, K., \& Pendek, J. (2017). Pengembangan Akselerometer Running Monitor Berbasis Android Untuk Mengetahui Karakteristik Lari Jarak Pendek. Pengembangan Akselerometer Running Monitor Berbasis Android Untuk Mengetahui Karakteristik Lari Jarak Pendek, 15(2), 193-208. https://doi.org/10.15294/sainteknol.v15i2.12405

Listiandi, A. D., Kusuma, M. N. H., Budi, D. R., Hidayat, R., Bakhri, R. S., \& Abdurahman, I. (2020). Pemanfaatan Aplikasi Smartphone untuk Meningkatkan Daya Tahan Kardiovaskuler dan Self-efficacy. Jendela Olahraga. https://doi.org/10.26877/jo.v5i2.5442

Meja, T., Dini, U., \& Kota, D. I. (2015). Journal of Physical Education, Health and Sport. 2(1), 38-43.

Nanang, M., Fuad, N., Didik, R., Topo, S., \& Panuwun, J. (2018). Effect of Alkaline Fluids to Blood $\mathrm{pH}$ and Lactic Acid Changes on Sub Maximal Physical Exercise. IOP Conference Series: Earth and Environmental Science. https://doi.org/10.1088/1755$1315 / 197 / 1 / 012049$

Rohman, U. (2019). Profil Kondisi Fisik Atlet PPLP Pencak Silat Jawa Timur. Journal Physical Education, Health and Recreation, 3(2), 112-121.

Suherman, W. S. (2019). Kontribusi IImu Keolahragaan Dalam Pembangunan Olahraga Nasional. Kontribusi IImu Keolahragaan Dalam Pembangunan Olahraga Nasional. https://doi.org/10.1017/CB09781107415324.004

Titting, Fellyson, Hidayah, Taufik, Pramono, H. (2016). Pengembangan Multimedia Pembelajaran Senam Lantai Berbasis Android Pada Pendidikan Jasmani Olahraga Dan Kesehatan Di Sma. Journal of Physical Education and Sports, 5(2), 120-126. https://doi.org/10.15640/jpesm

Umam, N., Setiawan, I., \& Pratama, B. A. (2020). SPRINTER : Jurnal IImu Olahraga Profil Kondisi Fisik Dan Ketepatan Shooting Sepakbola Pada Klub Suryanaga Utama FC Kabupaten Lamongan Tahun 2020. 1(1), 62-71. 